\title{
PENERAPAN ASAS ULTIMUM REMEDIUM DALAM KETENTUAN HUKUM PIDANA LINGKUNGAN DI INDONESIA
}

\author{
Oleh \\ Dian Adriawan Dg Tawang*) \\ dianadriawan63@gmail.com
}

\section{Abstrak}

Dampak terhadap kesehatan manusia terutama bersumber dari pencemaran lingkungan. Dampak pencemaran lingkungan dapat dirasakan setelah beberapa tahun atau puluhan tahun. Pencemaran lingkungan juga mengakibatkan rusaknya estetika dari lingkungan hidup atau lingkungan tempat tinggal manusia, seperti: gangguan adanya bau, kebisingan, asap atau kabut. Selain dampak pencemaran lingkungan, perusakan lingkungan hidup juga menjadi masalah yang tidak kalah pentingnya, misalnya penebangan hutan di Indonesia yang sudah tidak terkendali selama puluhan tahun dan hal menyebabkan terjadinya penyusutan hutan tropis secara besar-besaran yang sangat berdampak pada ekosistem hutan. Begitu juga perusakan lingkungan memberi dampak yang sangat merugikan masyarakat sekitar, bahkan masyarakat dunia. Kerugian yang diakibatkan oleh kerusakan hutan tidak hanya kerusakan secara nilai ekonomi, akan tetapi juga mengakibatkan hilangnya nyawa yang tidak ternilai harganya. Dampak lainnya adalah hilangnya paru-paru Indonesia dan dunia. Penempatan asas ultimum remedium dalam sumber hukum pidana hanya terdapat pada peraturan perundang-undang yang bersifat administrasi yang memuat ketentuan pidana, sedangkan dalam sumber hukum pidana yang berasal dari KUHP dan Peraturan perundang-undangan pidana berlaku asas premium remedium. Asas premium remedium adalah teori hukum pidana modern yang menyatakan bahwa hukum pidana sebagai alat utama dalam penegakan hukum. Keberadaan UUPPLH khususnya tentang penegakan hukum lingkungan terhadap delik formil, secara filosofis, sosiologis dan yuridis masih menimbulkan masalah, dan kurang memberi manfaan bagi perlindungan lingkungan, serta perumusan deliknya masih sangat kurang jelas sehingga telah melanggar asas lex certa yaitu asas kepastian.

\section{Kata Kunci : Hukum Pidana Lingkungan}

\section{A.PENDAHULUAN}

Kehidupan adalah fenomena atau perwujudan adanya hidup, yang didukung tidak saja oleh makluk hidup, tetapi juga benda mati dan berlangsung dalam dinamika seluruh komponen kehidupan itu. Dalam hubungan ini, lingkungan hidup adalah suatu konsep holistik yang berwujud di bumi ini dalam bentuk, susunan dan fungsi interaktif antara semua pengada, baik yang insani mau-

*) Penulis adalah Dosen Fakultas Hukum Universitas Trisakti pun yang ragawi. Keduanya saling mempengaruhi dan menentukan baik bentuk dan perwujudannya bumi dimana berlangsung kehidupan (biosfer) maupun bentuk dan perwujudan dari kehidupan itu sendiri. Dalam hal ini, lingkungan hidup manusia (human environment) adalah sistem dimana terdapat perwu- 
judan manusia atau dimana terdapat kepentingan manusia didalamnya. ${ }^{1}$

Lingkungan hidup dengan segala komponennya baik itu abiotik dan biotik merupakan daya dukung terhadap kehidupan manusia juga makhluk hidup lainnya. Adapun fungsi dari lingkungan hidup bagi manusia sebagai berikut:

1) Lingkungan hidup berfungsi sebagai wahana atau habitat, tempat manusia melangsungkan aktifitas kehidupannya.

2) Lingkungan hidup adalah tempat manusia mendapatkan makanannya.

3) Lingkungan hidup adalah tempat manusia bersosialisasi, mencari kekayaan, mendapatkan hiburan, edukasi dan lain lain.

4) Sebagai sumber kebudayaan. Adaptasi yang dilakukan manusia terhadap lingkungan lama kelamaan akan membentuk tradisi dan budaya.

Mengingat betapa pentingnya lingkungan hidup bagi kehidupan manusia, maka perlu dilakukan penjagaan agar lingkungan hidup tidak dirusak oleh tangan-tangan manusia yang menjadikan sumber penghidupan dalam rangka memenuhi kebutuhan hidup manusia dalam kesehariannya, sehingga dapat menimbulkan perubahan dan penurunan kualitas lingkungan hidup. Dampak negatif dari penurunan kualitas lingkungan hidup baik karena terjadinya pencemaran atau terkurasnya sumber daya alam adalah timbulnya ancaman atau dampak negatif terhadap kesehatan, menurunnya nilai estetika, kerugian ekonomi (economic cost), dan terganggunya sistem alami (natural system).

Dampak terhadap kesehatan manusia terutama bersumber dari pencemaran lingkungan. Dampak pencemaran ling-

1 A.M. Yunus Wahid, Pengantar Hukum Lingkungan, Prenadamedia Group, Jakarta, 2018, Halaman 2 kungan dapat dirasakan setelah beberapa tahun atau puluhan tahun. Pencemaran lingkungan juga mengakibatkan rusaknya estetika dari lingkungan hidup atau lingkungan tempat tinggal manusia, seperti: gangguan adanya bau, kebisingan, asap atau kabut. Selain dampak pencemaran lingkungan, perusakan lingkungan hidup juga menjadi masalah yang tidak kalah pentingnya, misalnya penebangan hutan di Indonesia yang sudah tidak terkendali selama puluhan tahun dan hal menyebabkan terjadinya penyusutan hutan tropis secara besar-besaran yang sangat berdampak pada ekosistem hutan. Begitu juga perusakan lingkungan memberi dampak yang sangat merugikan masyarakat sekitar, bahkan masyarakat dunia. Kerugian yang diakibatkan oleh kerusakan hutan tidak hanya kerusakan secara nilai ekonomi, akan tetapi juga mengakibatkan hilangnya nyawa yang tidak ternilai harganya. Dampak lainnya adalah hilangnya paru-paru Indonesia dan dunia. Pemanasan global, akan diikuti perubahan iklim, seperti naiknya curah hujan di beberapa belahan bumi yang menimbulkan bencana banjir dan tanah longsor, tetapi sebaliknya di belahan bumi lainnya mengalami kekeringan berkepanjangan.

Berdasarkan kondisi lingkungan hidup dan sebagai upaya menciptakan kelestarian fungsi lingkungan, maka Negara Indonesia mengatur dan menata lingkungan hidup dengan menerapkan aturan-aturan lingkungan. Adapun aturan lingkungan hidup tersebut adalah Undang-Undang Tentang KetentuanKetentuan Pokok Pengelolaan Lingkungan Hidup yang diawali dengan UndangUndang No. 4 Tahun 1982, kemudian Undang-Undang No. 23 Tahun 1997 Tentang Pengelolaan Lingkungan Hidup dan yang terakhir dengan UndangUndang No. 32 Tahun 2009 Tentang Perlindungan dan Pengelolaan Lingkungan Hidup. 
Undang-Undang No. 32 Tahun 2009 merupakan salah satu bentuk peraturan perundang-undang yang bersifat administrasi yang memuat ketentuan pidana, dan yang paling banyak dibuat serta berlaku di Indonesia yang memuat asas ultimum remedium. Asas ultimun remedium merupakan instrument yang diterapkan dalam dalam ketentuan tentang lingkungan hidup.

Penjelasan Umum atas UndangUndang No. 32 Tahun 2009 tentang Perlindungan dan Pengelolaan Lingkungan Hidup (UU PPLH) menyatakan dengan tegas bahwa penegakan hukum pidana lingkungan tetap memperhatikan asas ultimum remedium yang mewajibkan penerapan penegakan hukum pidana sebagai upaya terakhir setelah penerapan penegakan hukum administratif dianggap tidak berhasil.

Setelah melihat latar belakang di atas maka dirumuskan masalah berikut :

1. Sejauh mana penerapan asas ultimum remedium yang terdapat dalam hukum lingkungan?

2. Apa langkah yang harus ditempuh agar ketentuan hukum lingkungan dapat berjalan secara efektif?

\section{B. PEMBAHASAN}

\section{Sekilas tentang Ultimum Remedium}

Istilah ultimum remedium pertama kali diucapkan oleh Menteri Kehakiman Belanda, Mr. Modderman. Istilah ultimum remedium pertama kali dipergunakan oleh Modderman di depan parlemen negeri Belanda untuk menjawab pernyataan salah seorang anggota parlemen Belanda, yaitu Tuan Mackay, yang mengatakan bahwa ia telah gagal menemukan suatu dasar hukum mengenai perlunya suatu penjatuhan hukuman bagi seseorang yang telah melakukan suatu pelanggaran. ${ }^{2}$

Modderman, mengatakan : "saya percaya bahwa asas ini bukan saja selalu dapat dibaca di dalam peraturan-peraturan, melainkan juga berulang kali telah diucapkan, walaupun mungkin didalam bentuk yang lain. Asas tersebut adalah bahwa yang dapat dihukum itu pertamatama adalah pelanggaran-pelanggaran hukum. Ini merupakan conditio sine qua non. Kedua, adalah bahwa yang dapat dihukum itu adalah pelanggaran-pelanggaran hukum, yang menurut pengalaman tidaklah dapat ditiadakan dengan caracara yang lain. Hukuman itu hendaklah merupakan suatu upaya yang terakhir. Pada dasarnya terhadap setiap ancaman hukuman pastilah terdapat keberatankeberatan. Akan tetapi ini tidak berarti bahwa kita boleh mengabaikan penentuan tentang bilamana seseorang itu dapat dihukum,melainkan benar bahwa disitu orang harus membuat penilaian nengenai keuntungan dan kerugiannya serta harus menjaga agar hukum itu benarbenar menjadi upaya penyembuh dan jangan sampai membuat penyakitnya semakin lebih parah."3

Dalam perkembangan selanjutnya, asas ultimum remedium dikembangkan oleh Mr. De Bunt, bahwa asas ultimum remedium memiliki 3 macam pengertian, antara lain:

1) Hukum pidana itu hanya diterapkan terhadap perbuatan-perbuatan yang sangat tidak benar secara etis (hoog ethische onwaarde). Sebagai contoh Menteri Kehakiman Belanda pada tahun 1989 pernah mengucapkan, bahwa hukum pidana pada umumnya harus dilihat sebagai ultimum remedium. Maksud Menteri tersebut ada-

2 P.A.F. Lamintang, Dasar-Dasar Hukum Pidana Indonesia, Citra Aditya Bakti, Bandung, 1997, halaman 17-19

3 Ibid 
lah bahwa perbuatan beratlah yang harus ditanggulangi oleh hukum pidana. Di sini Menteri telah berbicara mengenai pengertian ultimum remedium secara klasik; hukum pidana itu adalah secara khusus merupakan instrumen penegakan hukum yang khusus. Jadi, penerapannya juga dalam hal-hal yang khusus. Harus dicegah bahwa obat jangan lebih berat daripada kejahatan. Hukum pidana itu merupakan alat yang sangat berat karena ciri khas pidana itu adalah nestapa yang dengan sengaja dikenakan. Oleh karena itu, hukum pidana harus dipandang sebagai ultimum remedium. Ultimum remedium didasarkan pada:

a) hukum pidana bersifat retributif;

b) pelanggaran hukum lingkungan pada hakikatnya tidak penting secara etis. ${ }^{4}$

2) Pengertian yang kedua mengenai ultimum remedium menurut De Bunt adalah dalam arti harfiah, yaitu alat (obat) yang terakhir yang diterapkan terhadap delik lingkungan. Hal ini dikemukakan oleh Menteri Kehakiman Belanda De Ruiter yang mengatakan hukum pidana sebagai alat yang terakhir. Hukum pidana menjadi obat yang terakhir karena membawa dampak sampingan yang merugikan. Hukum pidana menyinggung sangat dalam terhadap kehidupan pribadi terpidana (perampasan kemerdekaan, proses acara dengan alat paksa, dan noda), jadi mesti dilakukan dengan hati-hati. De Ross mengatakan bahwa walaupun tidak ada perbedaan antara sanksi hukum pidana dan sanksi administratif, namun sanksi hukum pidana itu relatif lebih berat karena pidana perampasan kemerdekaan

4 Mr. De Bunt, dalam Andi Hamzah, Penegakan Hukum Lingkungan, alumni, Bamndung, 2016, Halaman 123 merupakan sanksi yang menonjol. Penerapan hukum pidana dalam pengertian ultimum remedium seperti ini selalu dalam pilihan yang mana yang menguntungkan dan merugikan dalam pelbagai alat penegakan hukum. Pendapat yang demikian ini juga dibantah oleh De Bunt, karena katanya ada pelanggaran hukum lingkungan yang sanksi administratif dipandang terlalu berat dan tidak dapat diterapkan, misalnya perbuatan yang sekali saja terjadi, mungkin ringan, seperti tidak memenuhi kewajiban melapor, perusakan lingkungan yang tidak dapat dipulihkan, dan sebagainya. Yang kedua adalah tidak perlu dipertimbangkan sanksi administratif atau sanksi hukum pidana dalam penegakan hukum, seperti pada residivis yang penerapan hukum pidana menjadi pilihan. Maksudnya sudah pasti harus sanksi hukum pidana yang mestinya diterapkan. De Bunt membuktikan juga bahwa sanksi berat hukum pidana, yaitu pidana perampasan kemerdekaan ternyata jarang sekali diterapkan di Belanda. Bagaimana di Indonesia? Kelihatannya juga demikian, bahkan jarang sekali delik lingkungan dibawa ke pengadilan. Banyak pelanggaran justru ditindak dengan paksaan administratif seperti penggusuran kaki lima yang melanggar peraturan kebersihan kota. Yang diajukan seperti kasus Sidoarjo (akan dibicarakan di belakang) bahkan berakhir dengan dilepas dari tuntutan hukum oleh Pengadilan Negeri, tetapi kemudian Mahkamah Agung menjatuhkan pidana (Maret 1993). Alasan sebagai alat yang terakhir seperti dikemukakan oleh Petri dan Dorssen (keduanya sarjana lingkungan), bahwa penerapan instrumen hukum pidana baru diterapkan jika instrumen-instrumen lain telah gagal. Jadi, penerapan instru- 
men hukum pidana menduduki tempat sebagai subsider. Kalau demikian, kata De Bunt, penerapan instrumen hukum pidana menjadi alat yang pada akhirnya diterapkan. ${ }^{5}$

3) Pengertian ultimum remedium yang ketiga, yaitu pejabat administratiflah yang pertama-tama harus bertanggung jawab. Kalau pejabat administratif dipandang sebagai yang pertama-tama bertanggung jawab, dan oleh karena itu berarti bahwa kekuasaan yustisial ditempatkan sebagai ultimum remedium. Pejabat administrasi harus bereaksi terlebih dahulu. Yang memberi izin harus lebih dahulu memberi sanksi jika izin dilanggar. ${ }^{6}$

Oleh karena itu pengertian asas ultimun remedium sejalan dengan pendapat Sudikno Mertokusumo, dalam bukunya Penemuan Hukum Sebuah Pengantar mengartikan bahwa ultimum remedium sebagai alat terakhir. ${ }^{7}$

Mengenai asas hukum, Sudikno, antara lain; mengatakan bahwa asas hukum sifatnya abstrak, karena sifatnya itu, asas hukum pada umumnya tidak dituangkan dalam bentuk peraturan atau pasal yang konkrit, seperti:

1. Point d'interet point d'action (siapa yang mempunyai kepentingan hukum dapat mengajukan gugatan);

2. Restitutio in integrum (pengembalian kepada keadaan semula);

3. In dubio pro reo (dalam hal keraguraguan hakim harus memutuskan sedemikian hingga menguntungkan terdakwa);

4. Res judicata pro veritate habetur (apa yang diputus hakim harus dianggap benar);

5 Ibid

${ }^{6}$ Ibid

7 Sudikno Mertokusumo, Penemuan Hukum Sebuah Pengantar (Mertokusumo, Sudikno. Yogyakarta:Liberty,2006, halaman 128
5. Setiap orang dianggap tahu akan undang-undang;

6. Perlindungan terhadap pihak ketiga yang beritikad baik. ${ }^{8}$

Namun, berdasarkan penelusuran literature bahwa ultimum remedium merupakan salah satu asas yang terdapat dalam hukum pidana Indonesia yang mengatakan bahwa hukum pidana hendaklah dijadikan upaya terakhir dalam hal penegakan hukum. Hal ini memiliki makna apabila suatu perkara dapat diselesaikan melalui jalur lain (kekeluargaan, negosiasi, mediasi, perdata, ataupun hukum administrasi) hendaklah jalur tersebut terlebih dahulu dilalui.

Istilah ultimum remedium, diuraikan oleh Wirjono Prodjodikoro, mengatakan: ${ }^{9}$ norma-norma atau kaidah-kaidah dalam bidang hukum tata negara dan hukum tata usaha negara harus pertama-tama ditanggapi dengan sanksi administrasi, begitu pula norma-norma dalam bidang hukum perdata pertama-tama harus ditanggapi dengan sanksi perdata. Hanya, apabila sanksi administrasi dan sanksi perdata ini belum mencukupi untuk mencapai tujuan meluruskan neraca kemasyarakatan, maka baru diadakan juga sanksi pidana sebagai pamungkas (terakhir) atau ultimum remedium.

Lebih lanjut mengatakan bahwa sifat sanksi pidana sebagai senjata pamungkas atau ultimum remedium jika dibandingkan dengan sanksi perdata atau sanksi administrasi. Sifat ini sudah menimbulkan kecenderungan untuk menghemat dalam mengadakan sanksi pidana. Jadi, dari sini kita ketahui bahwa ultimum remedium merupakan istilah yang menggambarkan suatu sifat sanksi pidana. ${ }^{10}$

\footnotetext{
8 Ibid

9 Wirjono Prodjodikoro berjudul "Asas-Asas Hukum Pidana di Indonesia". Bandung: Refika Aditama, 2003, halaman 17

$10 \mathrm{Ibid}$, halaman 50
} 


\section{Pengertian Hukum Lingkungan Dalam Perkembangannya.}

Penyusunan Undang-Undang tentang Ketentuan-Ketentuan Pokok Pengelolaan Lingkungan Hidup yang diawali dengan Undang-Undang Nomor 4 Tahun 1982, kemudian Undang-Undang Nomor 23 Tahun 1997 tentang Pengelolaan Lingkungan Hidup, dan terakhir dengan Undang-Undang Nomor 32 Tahun 2009 tentang Perlindungan Dan Pengelolaan Lingkungan Hidup, berusaha untuk membuat definisi tentang lingkungan hidup sebagai berikut:

"Lingkungan Hidup adalah kesatuan ruang dengan semua benda, daya, keadaan, dan makhluk hidup, termasuk manusia dan perilakunya, yang mempengaruhi alam itu sendiri, kelangsungan perikehidupan, dan kesejahteraan manusia serta makhluk hidup lain".

Dalam literatur berbahasa Inggris hukum lingkungan disebut environmental law.Orang Belanda menyebutnya milieurecht, sedangkan Jerman menyebutnya umweltrecht, Prancis menamainya droit de environment. Malaysia dengan bahasa melayu memberi nama hukum alam sekitar, suatu istilah berbau harfiah. Semua istilah pelbagai bahasa bermaksud untuk menunjukkan bagian hukum yang bersangkutan dengan lingkungan fisik dan dapat diterapkan untuk mengatasi pencemaran, pengurasan, dan perusakan (verontreiniging, uitputting en aantasting) lingkungan (fisik). ${ }^{11}$

Jadi, pengertian hukum lingkungan di sini hanya meliputi lingkungan fisik saja dan tidak menyangkut lingkungan sosial. Misalnya tidak meliputi pence-

11 Th. Drupsteen, G. Kleijis-Wijnnobel, Handhaving Van Milieurecht Door Middle Van Civiel, Administratif en Srafrecht, Opstellen Over Het Milieustrafrecht, Arhem: Gouda Quint, 1991, halaman 4. maran kebudayaan Bali oleh turis asing yang membanjiri daerah itu.

Akan tetapi, masalah lingkungan berkaitan pula dengan gejala sosial, seperti pertumbuhan penduduk, migrasi, dan tingkah laku sosial dalam memproduksi, mengkonsumsi, dan rekreasi. Jadi, permasalahannya tidak semata-mata menyangkut ilmu alam, tetapi juga berkaitan dengan gejala sosial.

Hukum lingkungan pada umumnya bertujuan untuk menyelesaikan masalah lingkungan khususnya yang disebabkan oleh ulah manusia. Kerusakan lingkungan atau menurunnya mutu lingkungan disebabkan juga oleh bencana alam yang kadang-kadang sangat dahsyat, misalnya meletusnya Gunung Krakatau, gempa bumi yang memporak-porandakan lingkungan di Pulau Flores tahun 1992 dan gempa bumi yang menimpa kota bam di Iran 26 Desember 2003 yang menewaskan lebih dari 50.000 jiwa dan yang lukaluka tidak terhitung. Pada tanggal 26 Desember 2004 terjadi gelombang tsunami yang meluluhlantakan Provinsi Nanggroe Aceh Darussalam yang menewaskan 200 ratus ribu orang. Tanggal 11 Maret 2011 terjadi gempa dan tsunami di Fukushima Jepang yang mengakibatkan 500 korban jiwa selain yang luka-luka dan hilang serta kehancuran rumahrumah dan harta benda yang lain. Tahun 2015 terjadi kebakaran hutan yang luas di Sumatera yang menyebabkannn polusi asap yang luas sampai melintasi Negara ke Singapura dan Malaysia. Selain disebabkan oleh alam, juga oleh ulah manusia yang serakah. Tangggal 14 April 2016 terjadi lagi gempa di Kumamoto Jepang yang menewaskan lebih empat puluh orang dan ratusan kehilangan tempat tinggal.

Masalah lingkungan bagi manusia dapat dilihat dari segi menurunnya kualitas lingkungan. Kualitas lingkungan menyangkut nilai lingkungan untuk kesehatan, kesejahteraan, dan ketentraman 
manusia. Nilai lingkungan untuk berbagai bentuk pemanfaatan. Hilang dan berkurangnya nilai lingkungan karena pemanfaatan tertentu oleh umat manusia. Menurut Drupsteen, masalah lingkungan merupakan kemunduran kualitas lingkungan. Atau dengan kata lain, bahwa masalah lingkungan yang menyangkut gangguan terhadap lingkungan antara manusia dan lingkungan bentuknya berupa pencemaran, pengurasan, dan perusakan lingkungan.

Dilihat dari fungsinya, hukum lingkungan berisi kaidah-kaidah tentang perilaku masyarakat yang positif terhadap lingkungannya, langsung atau tidak langsung. Secara langsung kepada masyarakat hukum lingkungan menyatakan apa yang dilarang dan apa yang diperbolehkan. Secara tidak langsung kepada warga masyarakat adalah memberikan landasan bagi yang berwenang untuk memberikan kaidah kepada masyarakat. ${ }^{12}$

Jadi, hukum lingkungan mempunyai dua dimensi. Yang pertama adalah ketentuan tentang tingkah laku masyarakat, semuanya bertujuan supaya anggota masyarakat dihimbau bahkan kalau perlu dipaksa untuk memenuhi hukum lingkungan yang tujuannya memecahkan masalah lingkungan. Yang kedua, adalah dimensi yang memberi hak, kewajiban, dan wewenang badan-badan pemerintah dalam mengelola lingkungan.

\section{Hukum Pidana Lingkungan meng- adopsi Asas Ultimum Remedium Berada Dalam Masalah}

Dilihat dari sisi sumber hukum pidana, dapat dibagi tiga (3) bentuk sumber hukum, yakni; 1) Kitab UndangUndang Hukum Pidana (KUHP), 2) Peraturan Perundang-Undangan Pidana, misalnya: Undang-Undang No.31 Tahun 1999 Tentang Pemberantasan Tindak Pidana Korupsi, Undang-Udang No. 8

12 Th. Drupsteen,Ibid., halaman 3
Tahun 2010 Tentang Pencegahan dan Pemberantasan Tindak Pidana Pencucian Uang dan lain sebagainya, 3) Peraturan Perundang-undang yang bersifat administrasi yang memuat ketentuan pidana.

Penempatan asas ultimum remedium dalam sumber hukum pidana hanya terdapat pada peraturan perundangundang yang bersifat administrasi yang memuat ketentuan pidana, sedangkan dalam sumber hukum pidana yang berasal dari KUHP dan Peraturan perundang-undangan pidana berlaku asas premium remedium. Asas premium remedium adalah teori hukum pidana modern yang menyatakan bahwa hukum pidana sebagai alat utama dalam penegakan hukum.

Pentingnya asas ultimun remedium ditempatkan dalam peraturan perundangundang yang bersifat administrasi yang memuat ketentuan pidana adalah agar ketentuan administrasi ditaati atau untuk memberikan kewibawaan terhadap ketentuan administrasi.

Dalam ketentuan hukum lingkungan di Indonesia, yakni dalam UndangUndang No 23 tahun 1997 Pengelolaan Lingkungan Hidup, Penjelasan Atas Undang -Undang Republik Indonesia No. 23 Tahun 1997 Tentang Pengelolaan Lingkungan Hidup, diuraikan bahwa;

"Peningkatan pendayagunaan berbagai ketentuan hukum, baik hukum administrasi, hukum perdata maupun hukum pidana, dan usaha untuk mengefektifkan penyelesaian sengketa lingkungan hidup secara alternatif, yaitu penyelesaian sengketa lingkungan hidup di luar pengadilan untuk mencapai kesepakatan antar pihak yang bersengketa. Di samping itu, perlu pula dibuka kemungkinan dilakukannya gugatan perwakilan. Dengan cara penyelesaian sengketa lingkungan hidup tersebut diharapkan akan meningkatkan ketaatan masyarakat terhadap sistem nilai tentang 
betapa pentingnya pelestarian dan pengembangan kemampuan lingkungan hidup dalam kehidupan manusia masa kini dan kehidupan manusia masa depan. Sebagai penunjang hukum administrasi, berlakunya ketentuan hukum pidana tetap memperhatikan asas subsidiaritas, yaitu bahwa hukum pidana hendaknya didayagunakan apabila sanksi bidang hukum lain, seperti sanksi administrasi dan sanksi perdata, dan alternatif penyelesaian sengketa lingkungan hidup tidak efektif dan/ atau tingkat kesalahan pelaku relatif berat dan/atau akibat perbuatannya relatif besar dan/atau perbuatannya menimbulkan keresahan masyarakat". 13

Dalam penjelasan Atas UndangUndang Republik Indonesia No. 23 Tahun 1997 Tentang Pengelolaan Lingkungan Hidup tidak disebut asas ultimum remedium melainkan asas subsidiatas, namun memiliki pengertian yang sama dengan ultimun remedium, yakni bahwa hukum pidana hendaknya didayagunakan apabila sanksi bidang hukum lain, seperti sanksi administrasi dan sanksi perdata, dan alternatif penyelesaian sengketa lingkungan hidup tidak efektif dan/atau tingkat kesalahan pelaku relatif berat dan/atau akibat perbuatannya relatif besar dan/atau perbuatannya menimbulkan keresahan masyarakat".

Asas yang termuat pada bagian penjelasan umum Undang-Undang No.12 tahun 1997 Tentang Pengelolaan lingkungan Hidup ini, mensyaratkan tiga hal yang harus terpenuhi sebelum hukum pidana diterapkan. Ketiga syarat itu adalah sanksi bidang hukum lain tidak efektif, tingkat kesalahan pelaku atau akibatnya relatif besar dan menimbulkan keresahan masyarakat.

13 UU No. 23 Tahun 1997 tentang UndangUndang Pengelolaan Lingkungan Hidup
Guru Besar Hukum Lingkungan dari Universitas Padjajaran M. Daud Silalahi mengungkapkan, Undang-Undang Pengelolaan Lingkungan Hidup mengadopsi asas subsidiaritas dari Primary Jurisdiction Doctrine yang dianut oleh negaranegara penganut sistem hukum common law. Pertimbangan dimasukkannya asas ini dalam Undang-Undang Pengelolaan Lingkungan Hidup adalah terkait karakteristik dasar kasus-kasus lingkungan yang sangat bergantung pada penilaian keahlian. Kasus lingkungan sulit untuk dijabarkan secara hukum apabila tidak dilengkapi dengan pertimbangan-pertimbangan ilmiah. Dalam sistem hukum Amerika, kasus lingkungan bahkan disebut sebagai It's more technical rather than legal issue.

M. Daud Silalhi berpendapat bahwa asas subsidiaritas masih layak dan relevan untuk dipertahankan. Dia membantah anggapan yang mengatakan bahwa asas ini menunjukkan keberpihakan kepada kepentingan bisnis. Asas subsidiaritas justru dimaksudkan agar penyidik lebih hati-hati dalam penanganan kasus lingkungan, agar kasusnya kuat dan dapat dimenangkan. Asas subsi-diaritas akan tetap dipertahankan, namun pengaturannya akan diperjelas dan lebih komprehensif yaitu dimuat dalam batang tubuh dan penjelasan pasal; sehingga dalam penerapannya hakim tidak memiliki multitafsir.

Berbeda dengan M. Daud Silalahi, Mas Achmad Santosa, peneliti senior Indonesian Center for Environmetal Law (ICEL) memandang perlu menghilangkan asas subsidiaritas dalam hukum lingkungan. Asas subsidiaritas menurutnya sudah old-fashion (kuno). di Belanda pun juga demikian, karena dengan perkembangan teknologi yang begitu pesat, pengungkapan kejahatan korporasi tidak bisa lagi menggunakan asas subsidiaritas.

Sepengetahuan penulis, dalam penegakan hukum lingkungan di Belanda, 
sangat mengedepankan model pidana administratif. Latar belakang kebijakan hukum pidana yang demikian didasarkan pada kenyataan sulitnya pembuktian tindak pidana lingkungan hidup seperti yang saat ini dihadapi oleh Indonesia. Oleh karena itu, dibuatlah peraturan yang mengkriminalisasi tindakan-tindakan administrasi yang dianggap melanggar hukum.

Pada tahun 2009 dibuat ketentuan Perlindungan dan Pengelolaan Lingkungan Hidup yang memberi kesan, bahwa lingkungan hidup boleh dimanfaatkan namun harus dijaga kelestariannya. Hal ini sejalan dengan perkembangan hukum lingkungan internasional modern yang tidak hanya membebani manusia dengan suatu kewajiban untuk menjaga, melindungi dan melestarikannya, sebagaimana diungkapkan dalam Deklarasi Stockholm $1972 .{ }^{14}$

Berlakunya Undang-Undang No.32 Tahun 2009 Tentang Perlindungan dan Pengelolaan Lingkungan Hidup yang mengatur lingkungan hidup di Indonesia yang merupakan ketentuan hukum yang memiliki sifat administrasi dan di dalamnya terdapat hukum pidana. Sehingga bentuk dari hukum pidana merupakan hukum pidana administratif (administrative penal law).

Penegakan hukum pidana dalam undang-undang ini memperkenalkan ancaman hukuman minimum di samping maksimum, perluasan alat bukti, pemidanaan bagi pelanggaran baku mutu, keterpaduan penegakan hukum pidana, dan pengaturan tindak pidana korporasi.

Dalam Undang-Undang No. 32 Tahun 2009 Tentang Perlindungan dan Pengelolaan Lingkungan Hidup, penegakan hukum pidana lingkungan tetap memperhatikan asas ultimum remedium yang

14 Sukanda Husin, Penegakan Hukum Lingkungan Indonesia, Sinar Grafika, Jakarta, 2009, halaman 20 mewajibkan penerapan penegakan hukum pidana sebagai upaya terakhir setelah penerapan penegakan hukum administrasi dianggap tidak berhasil.

Walaupun dikatakan bahwa UndangUndang No. 32 Tahun 2009 terjadi pergeseran penilaian terhadap asas subsidiaritas nampaknya sedikit teratasi, karena adanya pengakuan terhadap asas ultimum remedium yang berkaitan dengan delik formil, bahwa penerapan penegakan hukum pidana sebagai upaya terakhir setelah penerapan penegakan hukum administrasi dianggap tidak berhasil.

Pengakuan adanya asas ultimun remediun dalam hukum pidana lingkungan, hanya berlaku bagi tindak pidana formil tertentu, yaitu pemidanaan terhadap pelanggaran baku mutu air limbah, emisi, dan gangguan.

Hal tersebut dilihat dalam uraian Pasal 100 Ayat (1) Undang-Undang No. 32 Tahun 2009, yang menyatakan:" Setiap orang yang melanggar baku mutu air limbah, baku mutu emisi, atau baku mutu gangguan dipidana, dengan pidana penjara paling lama 3 (tiga) tahun dan denda paling banyak Rp3.000.000.000,00 (tiga miliar rupiah). Kemudian ditegaskan didalam ayat (2), dinyatakan bahwa: "Tindak pidana sebagaimana dimaksud pada ayat (1) hanya dapat dikenakan apabila sanksi administratif yang telah dijatuhkan tidak dipatuhi atau pelanggaran dilakukan lebih dari satu kali". Sedangkan aturan hukum pidana yang diuraikan Bab XV selain Pasal 100 Undang-Undang No.32 Tahun 2009 diterapkan asas premium remedium, yang mengedepankan hukum pidana sebagai sarana atau alat utama dalam penegakan hukum lingkungan.

Ketergantungan penerapan hukum pidana disandarkan pada keadaan sanksi administrasi yang telah dijatuhkan tidak dipatuhi, atau pelanggaran dilakukan lebih dari satu kali. Hal ini mengandung pengertian bahwa pendayagunaan hu- 
kum pidana terhadap delik formil tertentu berlaku secara alternatif, boleh dipilih salah satu dari kedua hal tersebut. Artinya penerapan penegakkan hukum pidana dapat langsung diterapkan jika pelanggaran telah dilakukan lebih satu kali. Dengan demikian hukum pidana difungsikan secara premium remedium.

Kalimat yang menyatakan sansksi administrasi yang telah dijatuhkan tidak dipatuhi, tidak ada penjelasan lebih lanjut, karena saksi administrasi terdiri dari beberapa macam. Oleh karena itu sanksi hukum administrasi jenis mana yang diberikan pada pelanggar serta berapa kali sanksi administrasi dijatuhkan baru hukum pidana didayagunakan.

Begitu pula bila digantungkan pada pelanggaran dilakukan lebih dari satu kali, inipun tidak jelas apakah telah diberikan sanksi adminitrasi dan diulang kembali pelanggaran tersebut ataukah terdapat dua macam pelanggaran yang telah dilakukan. Semuanyanya menimbulkan adanya ketidakpastian hukum dalam pelaksanaannya.

Akibatnya ketika hukum pidana harus bersifat jelas, terang, lugas dan tidak multitafsir, dan agar menghindarkan dari adanya perbedaan pendapat dalam penanganan terhadap satu kasus lingkungan. Kelemahan semacam inilah yang menyebabkan asas subsidiaritas tidak dapat dioperasional pada penegakkan hukum pidana lingkungan.

Demikian pula bila digantungkan pada pelanggaran dilakukan lebih dari satu kali, inipun tidak jelas apakah telah diberikan sanksi administrasi dan diulang kembali pelanggaran tersebut, ataukah terdapat dua macam pelanggaran yang telah dilakukan. Semuanya ini potensial menimbulkan ketidakpastian hukum dalam tataran aplikatif. Karakter hukum acara yang baik harus bersifat jelas, terang, tegas dan tidak multi tafsir. Hal ini penting karena menghindarkan perbedaan pendapat dalam penanganan ter- hadap suatu kasus lingkungan. Kelemahan semacam inilah yang menyebabkan asas subsidiaritas tidak dapat dioperasionalkan pada penegakan hukum pidana lingkungan.

Ada kecenderungan yang kuat pada legislator yang menyatakan maanakala suatu penegakan hukum kurang efektif pelaksanaannya, maka undang-undangnya harus dirubah atau direvisi. Pendapat ini tidak selalu benar, karena sesungguhnya kelemahan tidak selalu pada perundang-undangan atau perangkat hukumnya namun juga pada aparat penegak hukumnya. Untuk itu aparat penegak hukumnya yang perlu mendapatkan penguatan agar dapat melaksanakan ketentuan undang-undang dengan baik. Jika undang-undangnya kurang jelas dalam perumusannya, maka seyogyanya perumusannya yang disempurnakan, tidak perlu dirubah secara keseluruhan.

Seharusnya, ketidakjelasan asas subsidiaritas dalam tatarannya aplikatif, tidak berarti asas tersebut dihapuskan dalam UUPPLH. Karena asas subsidiaritas ini sangat penting peranannya dalam upaya pencegahan terjadinya upaya pencemaran dan/atau perusakan lingkungan hidup. Asas subsidiaritas yang berhubungan dengan delik formil memberikan peranan utama atau terdepan kepada fungsi lembaga pengawasan yang dilakukan oleh rezim administrasi dalam mencegah terjadinya upaya pencemaran dan/atau perusakan lingkungan. Jika peran pencegahan dapat dioptimalkan peranannya, maka sesungguhnya pencemaran dan/atau perusakan liingkungan tidak akan terjadi, sehingga dengan demikian tidak akan menarik hukum pidana. Jika upaya ini setelah didayagunakan ternyata kurang efektif hasilnya barulah hukum pidana didayagunakan.

Dalam delik formil semacam ini biarlah peran hukum administrasi dikedepankan, hal ini dilakukan dalam rangka 
mengurangi terlalu saratnya peran hukum pidana seperti yang terjadi saat ini.

Jika fungsi penegakan hukum administrasi terhadap delik formil dapat berjalan dengan baik, maka sesungguhnya delik materil tidak pernah diterapkan, artinya tidak ada pelanggaran terhadap delik materiil kerena telah tercegah atau tertangani pada penegakan hukum administrasi ini.

Pemikiran seperti di atas ternyata tidak terakomodasi dalam UUPPLH saat ini, karena sebagian besar delik formil langsung dikenakan sanksi pidana minimal 1 (satu) tahun dan denda minimal Rp. 1.000.000.000,- (Satu milyar rupiah). Asas ultimum remedium hanya dibatasi untuk delik pelanggaran baku mutu air limbah, baku mutu emisi, atau baku mutu gangguan (pasal 100). Delik formil yang lain yaitu pasal 98-115, dan pasal selebihnya pengaturan tentang badan usaha lingkungan, hukum pidana langsung dioperasionalkan tanpa menunggu pelaksanaan hukum administrasi.

Legislator menggunakan paradigma penerapan fungsi hukum pidana primum remedium terhadap delik formil lainnya. Padahal upaya pencegahan dan perbaikan secara dini atas upaya pencemaran dan/atau perusakan lingkungan melalui hukum administrasi jauh lebih utama dan berdaya guna serta memberi manfaat yang lebih baik, dibandingkan bila hanya menyeret pelaku ke penjara tanpa adanya upaya pencegahan dan perbaikan lingkungan. Pemenjaraan seseorang khususnya dalam masalah lingkungan yang ringan tidak akan menyelesaikan masalah lingkungan. Biarkan hukum adminisitrasi bekerja, bila tidak berhasil barulah fungsi hukum pidana didayagunakan, kecuali terhadap delik materiil.

Kita tidak dapat membaca apa latar belakang perancangan undang-undang memberikan ancaman minimal 4 (empat) tahun dan denda minimal Rp.
100.000.000 (seratus juta rupiah) untuk delik formil yaitu delik belum selesai karena pencemaran dan/atau kerusakan lingkungan belum terjadi pelaku hanya melanggar larangan perundang-undangan seperti membuang limbah diatas batas baku mutu lingkungan yang diizinkan.

Secara ekstrim dapat digambarkan jika perundang-undangan menyatakan larangan membuang zat BOD5 limbah pabrik usahanya 3,001 hanya kelebihan 0,001. Berdasarkan pemeriksaan laboratorium sudah dapat dipastikan belum terjadi pencemaran apalagi perusakan lingkungan hidup, kalau mengacu pada Pasal 75 diatas maka pelaku usaha harus dihukum penjara 4 (empat) tahun, pantas atau patutkan pelaku usaha yang hanya melanggar hukum administrasi tersebut dihukum selama 4 (empat) tahun ditambah lagi dengan denda Rp. 100.000.000 (seratus juta rupiah). Bukankah rumusan undang-undang semacam ini sangat berlebihan dan akan sangat membebani negara bila terdakwa semacam ini harus diproses pidana dan berlama lama dihukum di lembaga permasyarakatan.

Akhir-akhir ini legislator selalu menarik semua persoalan ke ranah pidana (hukum pidana difungsikan primum remedium), sehingga nantinya hukum pidana akan kelebihan beban dan justru akan memberatkan upaya penegakan hukum itu sendiri.

Demikian pula kemunculan atas ultimum remedium dalam UUPPLH tidak diketahui proses pembahasannya, dalam RUUPPLH tidak terbaca asas dimaksud. Dalam daftar permasalahan yang muncul saat UUPLH berlaku, salah satu permasalahannya adalah keberadaan asas subsidiaritas, sehingga dalam rancangannya asas subsidiaritas tidak dimunculkan. tanpa diketahui proses pembahasannya tahu-tahu muncul asal ultimum remedium, menurut pidana, fungsi hukum pidana yang lain adalah primum remedium. Diangkan menjadi sebuah asas, karena 
akan ada lagi asas primum remedium sebagai kebalikan asas ultimum remedium.

Legislator dalam UUPPLH lebih menekankan pada upaya represif berupa penerapan penegakan hukum pidana. Penegakan hukum pidana diatur dalam 32 pasal, sedangkan pengaturan hukum perdata hanya diatur dalam 9 pasal, sementara pengaturan tentang hukum administrasi negara yang seharusnya lebih diperkuat hanya diatur dalam 9 pasal. Dari 32 pasal penegakan hukum pidana tersebut, hanya 2 pasal yang mengatur delik materil, pengaturan delik formil sebanyak 12 pasal, selebihnya berupa kriminalisasi terhadap pejabat amdan dan pejabat yang melalaikan tugasnya. Hanya 1 pasal yaitu pasal 100 ayat (2) dikenakan asas ultimum remedium penerapan penegakan hukum pidana harus menunggu dulu penegakan hukum administrasi dinyatakan gagal. Selebihnya terhadap 11 pasal delik formil yang lain tidak dikenakan asas ultimum remedium, hukum pidana difungsikan sebagai primum remedium, hukum pidana difungsikan sebagai primum remedium atau diutamakan artinya dapat langsung dilakukan penegakan hukum pidana.

Tidak ada penjelasan mengapa legislator memperlakukan asas ultimum remedium hanya terhadap baku mutu air limbah, baku mutu emisi dan baku mutu gangguan saja. Padahal karakteristik delik formil baru merupakan pelanggaran administrasi, yaitu berupa pelanggaran syarat atau izin yang ditetapkan. Hukum administrasi yang dikenakan sanksi pidana dikenal dengan administrative penal law.

Kecenderungan memfungsikan hukum pidana dalam masalah lingkungan sebagai primium remedium sangat menonjol dibandingkan dengan mendahulukan upaya hukum lain, padahal delik formil lebih dominan dibanding dengan delik materil, UUPPLH lebih menonjolkan pidana penjara bagi pelanggaran hukum administrasi yang justru belum melakukan pencemaran dan/atau perusakan lingkungan. Terlalu mengabaikan upaya pembenahan lingkungan sebagaimana yang seharusnya dilakukan oleh rezim hukum administrasi.

Dalam delik formil ini perbuatan pelaku ini dapat dikategorikan relatif ringan dan juga akibat perbuatannya belum berdampak besar bagi lingkungan, bahkan dapat saja belum ada dampaknya bagi lingkungan, bahkan saja belum ada dampaknya bagi lingkungan, atau karena itu tidak atau belum ada masyarakat yang resah. Sesuai dengan keterbatasan fungsi hukum pidana sebagaimana diuraikan diawal, maka seharusnya pelanggaran terhadap delik formil tersebut dahulu dilakukan tindakan hukum administrasi. Pencegahan serta pemulihan lingkungan dari upaya tercemar dan/atau rusak lebih utama dari sekedar memasukan seseorang ke penjara. Dipidananya seseorang atas pelanggaran hukum administrasi atau delik tidak dapat mencegah dan memulihkan alam dari tindkan pencemaran dan/atau perusakan lingkungan.

Seusai dengan pendapat Van de Bunt bahwa terhadap pelanggaran ringan dalam masalah lingkungan, seharusnya hukum pidana difungsikan secara ultimum remedium dan diprioritaskan penindakan terjadinya pelanggaran. Maka hukum pidana harus difungsikan secara ultimum remedium dan diprioritaskan penindakan terjadinya pelanggaran. Maka hukum pidana harus difungsikan secara ultimum remedium sebagai perangkat pamungkas, biarlah instrumen-instrumen hukum lainnya digunkan dalam rangka perlindungan lingkungan terhadap pelanggaran-pelanggaran ringgan. Dengan demikian kriminalisasi terhadap pelanggaran administrasi atau delik formil merupakan kebijakan yang berlebihan.

UUPPLH sebagai undang-undang payung, seharusnya legislator memper- 
tegas makna dan proses penerapan asas subsidaritas tersebut. Munculnya asas ultimum remedium potensial menimbulkan masalah baru yang lebih mendasar. Delik formil yang seharusnya cukup ditangani oleh hukum administrasi sebagai upaya preventif, dalam UUPPLH 15 dihapuskan. Penanganannya langsung diserahkan pada rezim hukum pidana sebagai upaya represif, keadaan semacam ini sangat betentangan dengan kebijakan hukum pidana, karena upaya hukum non penal seharusnya memberi ruang yang cukup besar sebelum menarik hukum pidana yang penuh dengan keterbatasan tersebut.

Penggunaan hukum pidana secara primum remedium seperti tersebut di atas justru bertentangan dengan penjelasan umum pada angka 5, bahwa upaya preventif dalam rangka pengendalian dampak lingkungan hidup perlu dilaksanakan dengan mendayagunakan secara maksimal instrumen pengawasan dan perizinan. Dalam hal pencemaran dan kerusakan lingkukan hidup perlu dilakukan upaya represif berupa penegakan hukum yang efektif, konsekuen dan konsisten terhadap pencemaran dan kerusakan lingkungan hidup terjadi.

Penjelasan umum angka 5 tersebut mempertegas bahwa penegakan hukum pidana atau upaya represif digunakan bila pencemaran dan kerusakan lingkungan hidup telah terjadi. Sedangkan terhadap delik formil seharusnya instrumen pengawasan dan perizinan yaitu hukum administrasi diupayakan semaksimal mungkin mungkin didayagunakan. Memperlakukan upaya represif terhadap

15 Dalam UUPPLH hukum administrasi hanya digunakan pada delik formil tertentu yang sangat terbatas, yaitu pelanggaran baku mutu air limbah, emisi, dan gangguan saja, sebagian besar penanganannya diserahkan pada hukum pidana. delik selain terhadap pelanggaran baku mutu air limbah, emisi dan gangguan.

Sebagaimana yang dikatakan Bagir Manan 16, bahwa suatu undang-undang yang baik harus memenuhi persyaratan sebagai berikut:

a. Sebuah undang-undang secara filosofis, sosiologis, dan yuridis harus memberikan manfaat untuk mengantarkan kepada keadaan yang lebih baik.

b. Keadaan yang baik tersebut apabila rakyat mengerti, karena memberi manfaat, bukan sebaliknya menimbulkan kegaduhan, kerancuan, bahkan kebingungan.

c. Suatu undang-undang yang bermanfaat bila mudah dilaksanakan bukan sebaliknya menjadi mahal baik dalam arti ekonomis, sosial dan politik.

d. Asas pokok membuat undang-undang adalah asas kehati-hatian (zorguuldigheid, carefulness.).

Berdasarkan uraian tersebut di atas, maka keberadaan UUPPLH khususnya tentang penegakan hukum lingkungan terhadap delik formil, secara filosofis, sosiologis dan yuridis masih menimbulkan masalah, dan kurang memberi manfaan bagi perlindungan lingkungan, serta perumusan deliknya masih sangat kurang jelas sehingga telah melanggar asas lex certa yaitu asas kepastian.

\section{PENUTUP}

1. Pada prinsipnya penerapan asas ultimum remedium yang terdapat dalam hukum lingkungan masih diakui keberadaaannya dan berlaku sebagai asas yang digunakan dapat penegakan hukum pidana administratif, namun dalam Undang-Undang No.32

16 Dalam Varia peradilan majalah hukum tahun XXV No. 294 Mei 2010, Hukum Materil Perkawinan Di Lingkungan Peradilan Agama, Halaman 37 
tahun 2009 peran asas Ultimun remedium hanya tergambar dalam penerapan delik formil saja, yakni dalam pasal 100.

2. Seharusnya ada kesamaan pandangan antara legislator dan pakar hukum pidana lingkungan mengenai keberadaan asas ultimum remedium ini, karena apabila semua persoalan lingkungan hidup diterapkan hukum pidana maka hukum pidana kelebihan beban dan justru akan memberatkan upaya penegakan hukum pidana itu sendiri.

\section{DAFTAR PUSTAKA}

Andi Hamzah, Penegakan Hukum Lingkungan, alumni, Bamndung, 2016.

A.M.Yunus Wahid, Pengantar Hukum Lingkungan, Prenadamedia Group, Jakarta, 2018.

P.A.F. Lamintang, Dasar-Dasar Hukum Pidana Indonesia, Citra Aditya Bakti, Bandung, 1997.

Sukanda Husin, Penegakan Hukum Lingkungan Indonesia, Sinar Grafika, Jakarta, 2009.

Sudikno Mertokusumo, Penemuan Hukum Sebuah Pengantar, Yogyakarta, liberty, 2006.

Th. Drupsteen, G. Kleijis-Wijnnobel, Handhaving Van Milieurecht Door Middle Van Civiel, Administratif en Srafrecht , Opstellen Over Het Milieustrafrecht, Arhem: Gouda Quint, 1991.
Wirjono Prodjodikoro, "Asas-Asas Hukum Pidana di Indonesia”. Bandung: Refika Aditama, 2003 